Jurnal Syntax Imperatif: Jurnal Ilmu Sosial dan

Pendidikan

p-ISSN: 2721-2491 e-ISSN: 2721-2246

Vol. 2, No. 1, Maret 2021

\title{
Internalisasi Nilai-Nilai Karakter pada Anak Melalui Model Pembelajaran Beyond Center and Circle Time (BCCT) di TKIT Luqmanul Hakim
}

\author{
Anie Rohanie \\ Sekolah Tinggi Agama Islam (STAI) Persis Bandung, Indonesia \\ anirohaeni@38gmail.com
}

\begin{abstract}
Abstrak
Pendidikan anak usia dini atau sering yang disingkat Paud adalah pendidikan yang diberikan kepada anak usia nol sampai enam tahun. Pendidikan anak usia dini disebut juga pendidikan usia prasekolah, taman bermain, atau taman kanak - kanak. BCCT atau Beyond Center and Circle Time menurut Nidar (2009: 53), Merupakan suatu pendekatan dalam pendidikan anak usia dini dimana dalam pelaksanaannya anak dituntut aktif dan kreatif dalam kegiatan disentra-sentra, artinya anak aktif mencoba dan bereksperimen sendiri sehingga anak belajar dari pengalaman yang diperolehnya. Metode penelitian yang digunakan dalam penelitian ini adalah metode penelitian kualitatif. Adapun hasil yang diperoleh, penanaman nilai-nilai karakter disini, diantaranya adanya tempat, sarana dan prasarana seperti, gedung sekolah, ruang kelas, ruang guru, media sentra yang mendukung terselenggaranya proses pembelajara sentra, goodwill Yayasan yang mengizinkan dan mendukung unit TK untuk menggunakan model pembelajaran sentra, Lembaga memberi kesempatan bagi guru, khususnya tim kurikulum untuk mendalami ilmu tentang sentra, baik melalui pelatihan maupun study banding. Kesimpulan yang didapat Evaluasi Internalisasi nilai-nilai karakter pada anak melalui model pembelajaran BCCT (Beyond Centers and Circle Time) di TKIT Luqmanul Hakim menggunakan catatan anekdot dilakukan untuk melakukan pencatatan mengenai perilaku-perilaku anak, tidak hanya perilaku buruk anak saja yang dicatat namun mencatat juga perilaku baik anak
\end{abstract}

Kata kunci: Karakter; Anak; Beyond Center and Circle Time (BCCT);

\section{Pendahuluan}

Taman kanak - kanak merupakan salah satu lembaga pendidikan anak usia dini yang terdapat dalam jalur pendidikan formal. Sesuai dengan tujuan TK menurut undang - undang Republik Indonesia Nomor 20 Tahun 2003 Tentang Sistem Pendidikan Nasional Bab VI pasal 28 ayat 3 berbunyi:

"Pendidikan Anak Usia Dini pada jalur pendidikan formal berbentuk Taman Kanak - Kanak, Raudatul Athfal atau bentuk lain yang sederajat. Pendidikan bagi anak usia 4 sampai 6 tahun. Usia 4 sampai 6 tahun ini merupakan usia yang paling efektif untuk mengembangkan berbagai potensi yang dimiliki anak" (Muliawan, 2009, p. 15)

Pendidikan anak usia dini atau sering yang disingkat Paud adalah pendidikan yang diberikan kepada anak usia nol sampai enam tahun. Pendidikan anak usia dini disebut juga pendidikan usia prasekolah, taman bermain, atau taman kanak - kanak.

Penyelenggaraan PAUD harus lebih berorientasi pada pembelajaran yang berbasis karakter. Karena terpuruknya bangsa Indonesia sekarang ini disebabkan oleh terpuruknya dunia Pendidikan anak. Pendidikan anak di Indonesia akhir-akhir ini dinilai sarat dengan muatan-muatan pengetahuan dan tuntutan arus global yang mana mengesampingkan 
nilai-nilai moral budaya dan budi pekerti dalam membentuk karakter anak, sehingga menghasilkan anak yang pintar tetapi tidak bermoral. Fenomena ini sesungguhnya menjadi tantangan bagi bangsa Indonesia, dimana pendidikan itu seharusnya mampu menjadi suatu wadah untuk mengembangkan dan membentuk watak serta peradaban bangsa.

Untuk itu diperlukan suatu sistem pendidikan yang menanamkan nilai-nilai karakter pada anak sejak dini. Pendidikan karakter dipilih sebagai suatu upaya perwujudan pembentukan karakter peserta didik ataupun generasi bangsa yang berakhlak mulia. Rahardjo (2010:16) berpendapat bahwa:

"Pendidikan karakter adalah suatu proses pendidikan yang holistik yang menghubungkan dimensi moral dengan ranah sosial dalam kehidupan peserta didik sebagai fondasi bagi terbentuknya generasi yang berkualitas yang mampu hidup mandiri dan memiliki prinsip suatu kebenaran yang dapat dipertanggung jawabkan. (Adisasmita, 2006, p. 16)

Berdasarkan penjelasan di atas, maka dapat diambil kesimpulan bahwa dalam mewujudkan pendidikan yang berkarakter adalah dengan mampu menanamkan nilai-nilai karakter kepada peserta didik sebagai fondasi agar terbentuknya generasi yang berkualitas yang mampu hidup mandiri dalam kehidupan sehari-hari. Sehingga nantinya bisa menjadi manusia insan kamil yang memiliki prinsip suatu kebenaran yang dapat dipertanggungjawabkan.

Untuk meningkatkan efisiensi pembelajaran, pemerintah mengadopsi salah satu model pembelajaran yaitu model pembelajaran BCCT (Beyond Centers and Circle Time). Lebih lanjut Sujiono menjelaskan bahwa model pembelajaran BCCT (Beyond Centers and Circle Time) adalah suatu metode atau pendekatan dalam penyelenggaraan pendidikan anak usia dini yang merupakan perpaduan antara teori dan praktik (Sujiono \& Sujiono, 2010, p. 7)

Kurikulum BCCT diarahkan untuk membangun pengetahuan anak dan karakter yang digali oleh anak itu sendiri. Anak didorong untuk bermain di sentra-sentra kegiatan. Sedangkan pendidik berperan sebagai perancang, pendukung dan penilai kegiatan anak. Pembelajaran bersifat individual sehingga rancangan, dukungan, dan penilaiannya pun disesuaikan dengan tingkatan perkembangan di kebutuhan tiap anak.

Semua tahapan perkembangan anak dirumuskan dengan rinci dan jelas, sehingga guru memiliki panduan dalam penilaian perkembangan anak dalam pembentukan karakter. Kegiatan pembelajaran tertata dalam urutan yang jelas. Dari penataan lingkungan bermain sampai pada pemberian pijakan-pijakan.

Setiap anak memperoleh dukungan untuk aktif, kreatif, dan berani mengambil keputusan sendiri tanpa mesti tahu membuat kesalahan, jika salahpun guru memberikan peluang kepada untuk mencari kesalahannya dan memperbaikinya sehingga anak tersebut mempunyai karakter bertanggung jawab atas kesalahannya. Setiap tahap perkembangan bermain anak dirumuskan secara jelas, sehingga dapat menjadi acuan bagi pendidik melakukan penilaian. Penerapan BCCT tidak bersifat kaku. Dapat dilakukan secara bertahap, sesuai situasi dan kondisi setempat. 
Internalisasi nilai-nilai karakter pada salah satu TK di salah satu Kecamatan di Bandung belum secara konsisten dilakukan, sehingga Internalisasi nilai-nilai karakter belum sepenuhnya berhasil. Internalisasi nilai-nilai karakter ini harus dilakukan dengan konsisten agar benar-benar bisa dihayati dan dilaksanakan oleh anak. Alasan-alasan belum konsistennya pelaksanaan pendidikan karakter yang peneliti ketahui salah satunya yaitu, guru kadang memberikan peringatan ketika anak melakukan kesalahan namun kadang guru juga tidak memberikan peringatan ketika anak melakukan kesalahan. Ketidak konsistenan guru dalam memberikan peringatan tersebut membuat pembiasaan perilaku baik belum terwujud.

Karakter adalah ciri atau karakteristik atau gaya atau sifat khas dari diri seseorang yang bersumber dari bentukan-bentukan yang diterima dari lingkungan, misalnya keluarga pada masa kecil, dan juga bawaan seseorang sejak lahir (Sjarkawi, 2006, p. 1)

Karakter sendiri menurut etimologi berasal dari bahasa Yunani yaitu karasso yang berarti cetak biru, format dasar, dan sidik seperti dalam sidik jari (A Doni Koesoema, 2011, p. 90) Dalam hal ini karakter diartikan sebagai sesuatu yang tidak dapat dikuasai oleh intervensi manusia. Dengan kata lain karakter antara satu orang dengan yang lain berbeda-beda dan tidak ada yang sama seperti halnya sidik jari. Pendapat lain menyebutkan bahwa karakter erat hubungannya dengan personality atau kepribadian seseorang (Zubaedi, 2011, p. 10). Pengertian ini memberikan gambaran bahwa segala ucapan dan tindakan yang ditunjukkan oleh seseorang dalam berperilaku merupakan bentuk dari karakter. Menurut Fasli Jalal sebagaimana dikutip (Fadlillah \& Khorida, 2013, p. 21) karakter ialah nilai-nilai yang khas baik (tahu nilai kebaikan, mau berbuat baik, nyata berkehidupan baik, dan berdampak baik terhadap lingkungan) terpatri dalam diri dan terwujud dalam perilaku.

Dari beberapa definisi tersebut dapat dipahami bahwa karakter merupakan kepribadian yang dimiliki oleh seseorang yang telah menjadi sebuah watak atau tabiat yang sulit untuk dihilangkan, sehingga menjadi cerminan dalam berperilaku setiap hari. Karakter ini menjadikan perbedaan antara satu orang dengan yang lainnya.

Menurut Wismiarti (dalam kasali 2019:208) metode sentra mengembangkan 18 sikap yang kemudian menjadi pegangan perilaku. Ini merupakan tata nilai (values) karakter yang di sar'i kan dari ajaran islam diantaranya 1). Mutu 2). Hormat 3). Jujur 4). Bersih 5). Kasih Sayang 6). Sabar 7). Syukur 8). Ikhlas 9). Disiplin 10). Tanggung Jawab 11) Khusuk 12) Rajin 13). Berfikir positif 14). Ramah 15). Rendah hati 16). Takwa 17) istikamah 18). Qanaah (Rhenald Kasali, 2019, p. 159)

Selain itu nilai-nilai pendidikan karakter terkandung dalam Surah Luqman ayat 1219 dimana secara garis besar mengandung nilai pendidikan karakter : syukur, bijaksana, amal salih, sikap hormat, ramah, sabar, rendah hati, dan pengendalian diri.

Nilai-nilai karakter diatas akan menunjukkan jati dirinya sebagai manusia yang sadar diri sebagai makhluk, manusia, warga negara, dan pria atau wanita. Kesadaran itu dijadikan ukuran martabat dirinya sehingga berpikir obyektif, terbuka, dan kritis, serta memiliki harga diri yang tidak mudah memperjualbelikan. Sosok dirinya tampak memiliki integritas, kejujuran, kreativitas, dan perbuatannya menunjukkan produktivitas. 
Selain itu, tidak hanya menyadari apa tugasnya dan bagaimana mengambil sikap terhadap berbagai jenis situasi permasalahan, tetapi juga akan menghadapi kehidupan dengan penuh kesadaran, peka terhadap nilai keramahan sosial, dan dapat bertanggung jawab atas tindakannya.

1. BCCT (Beyond Centers and Circle Time)

BCCT atau Beyond Center and Circle Time menurut Nidar (2009: 53), terjemahan dalam bahasa Indonesia "sentra dan lingkaran". Merupakan suatu pendekatan dalam pendidikan anak usia dini dimana dalam pelaksanaannya anak dituntut aktif dan kreatif dalam kegiatan disentra-sentra, artinya anak aktif mencoba dan bereksperimen sendiri sehingga anak belajar dari pengalaman yang diperolehnya.

Menurut, (Depdiknas, 2006, p. 2), menguraikan pendekatan sentra dan lingkaran merupakan suatu pendekatan dalam Pendidikan Anak Usia Dini (PAUD) yang fokus pada anak, yang pada proses pembelajarannya berpusat di sentra main dan menggunakan empat jenis pijakan antara lain: pijakan lingkungan main, pijakan sebelum main, pijakan selama main, dan pijakan setelah main.

Metode ini juga memberikan peluang merangsang seluruh aspek kecerdasan anak (multiple intelligence) melalui bermain yang terarah, karena bermain juga merupakan tuntunan dan kebutuhan yang esensial bagi anak usia dini. Melalui bermain anak akan dapat memuaskan tuntutan dan kebutuhan perkembangan dimensi motorik, kognitif, kreatifitas, bahasa, emosi, sosial, nilai-nilai, dan sikap hidup. Beyond Center and Circle Time (BCCT) adalah pendekatan pembelajaran yang menggunakan konsep "anak adalah unik", artinya bila dilakukan pendidikan terhadap anak usia dini misalnya 20 anak, maka akan menghasilkan 20 hasil karya yang berbeda meskipun bahan ajar yang digunakan sama.

Internalisasi Nilai-Nilai karakter pada anak masuk dalam Tingkat Pencapaian Perkembangan Anak sesuai Peraturan Menteri Pendidikan dan kebudayaan Nomor 137 tahun 2014 di antaranya dalam Nilai agama dan moral dan juga di Sosial Emosional anak

\section{Metode Penelitian}

Metode penelitian yang digunakan dalam penelitian ini adalah metode penelitian kualitatif. Menurut Afifuddin dan Saebani (2012:57) Metode Penelitian Kualitatif ini sering disebut metode penelitian naturalistic karena penelitiannya dilakukan pada kondisi yang alamiah (natural setting), disebut juga sebagai metode etnografi karena pada awalnya, metode ini lebih banyak digunakan untuk penelitian di bidang antropologi budaya, dan disebut sebagai metode kualitatif karena data terkumpul dan analisanya lebih bersifat kualitatif (Afifuddin \& Saebani, 2012, p. 57)

\section{Hasil Dan Pembahasan}

A. Hasil

1. Perencanaan Internalisasi Nilai-Nilai Karakter Pada Anak Melalui Model Pembelajaran Beyond Centers and Circle Times (BCCT) di TKIT Luqmanul Hakim 
Kegiatan yang pertama dilakukan oleh Guru Sentra dalam persiapan mengajar adalah menyusun Rencana Pelaksanaan Pengajaran (RPP). RPP ini disusun berdasarkan materi yang terdapat di dalam kurikulum DEPDIKNAS dan Jaringan Sekolah Islam Terpadu (JSIT). Tujuan dari penyusunan ini adalah agar kegiatan pembelajaran dapat berjalan secara sistematis sesuai rencana. Agar penyusunan RPP ini sesuai dengan kebutuhan siswa.

Nilai-nilai karakter diambil dari kurikulum 2013 yang dipadukan dengan kurikulum Jaringan Sekolah Islam Terpadu (JSIT) dimana banyak di pengembangan NAM dan Sosial-emosionalnya. Tujuan dari penyusunan ini adalah agar kegiatan pembelajaran dapat berjalan secara sistematis sesuai rencana. Agar penyusunan RPP ini sesuai dengan kebutuhan siswa.

Perumusan RPP dilakukan seminggu sebelum pembelajaran dimulai, dalam RPP perilaku jujur, menolong, sopan, hormat, sportif adalah menu wajib yang disajikan di sentra ini. Hal ini untuk mengetahui seberapa jauh perkembangan karakter anak yang telah dibiasakan di sentra ini. Dalam perumusan RPP juga banyak nilai-nilai karakter yang diambil karena menurut para guru dengan setiap hari dinilai maka akan diketahui perkembangan karakter anak, tanpa mengesampingkan aspek perkembangan yang lainnya.

RPP kelas A dan RPP kelas B masing-masing satu minggu, jadi dua minggu dengan dua RPP untuk kelas A dan B. Misalnya di sentra persiapan hari senin adalah kelompok jeruk (kelas B), hari selasa kelompok apel (Kelas B) dengan permainan yang sama dengan kelompok jeruk hingga ke enam kelompok dapat mengikuti permainan tersebut, begitu pula dengan sentra yang lainnya.

Dalam menentukan kegiatan, guru sentra harus mencari kegiatan yang sesuai dengan Kompetensi Inti dan Kompetensi Dasar (KI-KD) serta Indikator yang telah disusun guru sentra dalam RPP. Setiap sentra tentunya berbeda beda dalam kegiatan pembelajaran dan berbeda pula kebutuhan perkembangan anak. Guru diwajibkan kreatif agar anak tidak bosan ketika belajar, media pembelajaran setiap minggu harus berganti dan memerlukan kreatifitas yang tinggi untuk membuat media pembelajaran, bisa lihat di internet atau di buku, sebagian ada media yang siap pakai.

Ada enam kelompok anak yang akan bermain sentra, maka setiap kelompok harus memenuhi kegiatan RPP yang telah disusun perminggunya. Satu RPP untuk enam kelompok main maka setiap kelompok berhak menerima pembelajaran dari RPP tersebut. Jika RPP diganti setiap hari maka kelompok lain tidak bisa mengikuti pembelajaran yang telah disusun, maka setiap kelompok akan berbeda-beda materinya, ini akan merugikan kelompok yang tidak ikut pembelajaran, anak akan bingung karena materi pembelajaran berbeda dengan kelompok lain, karena setiap anak akan berkomunikasi dengan temannya dan membahas permainan yang telah dimainkan.

Ada beberapa kegiatan yang sama dengan minggu kemarin ada yang diganti, biasanya kegiatan yang sama dengan minggu kemarin adalah kegiatan yang belum anak kuasai, maka kegiatan tersebut tidak diganti hingga anak kuasai dengan baik, adapun kegiatan yang diganti yaitu kegiatan yang telah dikuasai oleh anak. Kegiatan yang sesuai 
tema itu yang membutuhkan kreatifitas yang tinggi, karena dalam satu sentra bisa lebih dari sepuluh kegiatan yang akan dimainkan oleh anak, misalnya tema tanaman dengan sub tema tanaman hias dan sub subtema Bunga matahari, maka dalam sepuluh permainan itu harus terselip tema tersebut, bisa dari aspek kognitif, bahasa, motorik kasar dan halus.

Kecerdasan anak sangat di hargai disini dengan pembelajaran yang mengembangkan Multiple Intelligence Program kegiatan yang sebelumnya ekstrakurikuler dimasukkan ke dalam kegiatan intrakurikuler, yaitu menari, menyanyi, futsal, mobis, menggambar, melukis dan angklung.

\section{Pelaksanaan Internalisasi Nilai-Nilai Karakter Pada Anak Melalui Model Pembelajaran Beyond Centers and Circle Times (BCCT) Di TKIT Luqmanul Hakim}

Pelaksanaan pendidikan karakter di TKIT Luqmanul Hakim dimana pendidikan TKIT Luqmanul Hakim berbeda dengan instansi-instansi lain. Di Luqmanul Hakim pendidikan karakter lebih ditanamkan. Contohnya tidak diajarkan anak lulus dari TK bisa membaca dan menulis tetapi di TK ditanamkan untuk menyukai membaca dan menulis berarti dari segi pendidikan untuk TK tidak terlalu formal tapi penanaman untuk mencintai membaca dan menulis, kebersamaan, hidup mandiri seperti itu yang ditanamkan dan termasuk pendidikan karakter.

Penanaman nilai karakter pada recalling juga diperhatikan karena disini tertanam sikap kejujuran dimana anak akan menjelaskan apa saja yang mereka kerjakan secara runut. Guru yang memonitor pekerjaan anak-anak akan meluruskan jika ternyata anak mengucapkan hal yang tidak sesuai dengan apa yang tadi dia kerjakan. Selain kejujuran juga ditanamkan rasa hormat kepada temannya yang sedang menjelaskan pekerjaaanya saat recalling. Maka teman yang lainnya menghormati dengan mendengarkan temannya yang sedang berbicara atau menyampaikan pekerjaannya dengan runut. Setelah satu persatu anak menjelaskan pekerjaannya selesai, waktunya berdoa dan anak-anak dipersilahkan kembali ke kelasnya masing-masing dan sentra pun ditutup.

Penanaman nilai karakter yang terdapat pada pijakan setelah bermain yaitu bertanggung jawab atas permainan atau peralatan yang mereka mainkan, kejujuran saat menjelaskan dan menghitung permainan secara runut dan menghormati teman yang sedang menjelaskan pekerjaannya. Penanaman nilai karakter pada pijakan setelah bermain dikatakan berhasil sesuai harapan.

\section{Evaluasi Internalisasi Nilai-Nilai Karakter Pada Anak Melalui Model Pembelajaran Beyond Centers and Circle Times (BCCT) Di TKIT Luqmanul Hakim}

Pencatatan kegiatan belajar anak dilakukan setiap pertemuan dengan cara mencatat perkembangan kemampuan anak dalam hal Motorik Kasar dan halus, Bahasa, Kognitif, Sosial Emosional dan aspek-aspek lainnya hal ini di sampaikan oleh beberapa guru sentra TKIT Luqmanul Hakim. Biasanya ketika pijakan saat bermain ada guru yang menilai, 
hanya saja indikator tentang karakter minimal satu hari 5 karakter yang dinilai, sisanya kegiatan inti. Evaluasi yang dilaksanaan pada pendidikan karakter TKIT Luqmanul Hakim yaitu menggunakan catatan standar-standar yang harus dicapai anak dan menggunakan catatan anekdot.

Evaluasi dari pendidikan karakter juga dapat berupa teguran guru jika ada sifat anak yang kurang baik. Pelaksanaan evaluasi menggunakan catatan anekdot dilakukan untuk melakukan pencatatan mengenai perilaku-perilaku siswa, tidak hanya perilaku buruk anak saja yang dicatat namun mencatat juga perilaku baik anak. Evaluasi dari pendidikan karakter TKIT Luqmanul Hakim juga menggunakan catatan penilaian yang telah disusun dengan RKH, penilaian dilakukan ketika dipijakan sebelum bermain hingga recalling.

Penilaian melalui pengamatan dilakukan oleh guru dengan mengamati aktivitas siswa sehari-hari yang berhubungan dengan penanaman nilai karakter. Evaluasi pembelajaran yang dilakukan disini berupa pengamatan, catatan anekdot dan portofolio. Penilaian melalui pengamatan dilakukan oleh guru dengan mengamati aktivitas siswa sehari-hari yang berhubungan dengan nilai karakter. Penilaian melalui catatan anekdot dilakukan dengan mencatat perkembangan motorik kasar dan motorik halus siswa, dan mengamati aktivitas sosial siswa, baik antara siswa dengan siswa maupun antara siswa dengan guru. Penilaian melalui portofolio dilakukan dengan menggunakan hasil belajar siswa yang berupa gambar atau pekerjaan rumah. Penilaian untuk penanaman nilai karakter hanya berupa pengamatan dan pencatatan di catatan anekdot dimana ada nilai karakter yang baik dan kurang baik.

Evaluasi yang dilaksanaan pada penanaman nilai-nilai karakter di TKIT Luqmanul Hakim melalui model pembelajaran BCCT yaitu berupa pengamatan dan pencatatan menggunakan catatan standar-standar yang harus dicapai anak dan menggunakan catatan anekdot. Evaluasi dari penanaman karakter juga dengan cara mengingatkan guru kepada anak jika ada sifatnya yang kurang baik.

Tidak hanya internalisasi karakter saja tetapi pelaksanaan evaluasi menggunakan catatan anekdot dilakukan pencatatan mengenai perilaku-perilaku siswa, perilaku yang tidak sesuai pada anak saja yang dicatat namun mencatat juga perilaku yang sesuai pada anak. Evaluasi terhadap anak juga dilakukan guru dengan mengingatkan anak secara langsung.

Internalisasi Nilai-Nilai Karakter Pada Anak Melalui Model Pembelajaran Beyond Centers and Circle Times (BCCT) Di TKIT Luqmanul Hakim didukung oleh beberapa faktor yang menunjang keberhasilan pelaksanaan pendidikan karakter tersebut. Faktor pendukung untuk penanaman nilai-nilai karakter disini, diantaranya adanya tempat, sarana dan prasarana seperti, gedung sekolah, ruang kelas, ruang guru, media sentra yang mendukung terselenggaranya proses pembelajara sentra, goodwill Yayasan yang mengizinkan dan mendukung unit TK untuk menggunakan model pembelajaran sentra, Lembaga memberi kesempatan bagi guru, khususnya tim kurikulum untuk mendalami ilmu tentang sentra, baik melalui pelatihan maupun study banding.

\section{B. Pembahasan}




\section{Perencanaan Internalisasi Nilai-Nilai Karakter Pada Anak Melalui Model Pembelajaran Beyond Centers and Circle Times (BCCT) Di TKIT Luqmanul Hakim.}

Berdasarkan dari hasil penelitian bahwa Perencanan Internalisasi Nilai-Nilai Karakter pada Anak Melalui Model Pembelajaran Beyond Centers and Circle Times (BCCT) di TKIT Luqmanul Hakim diawali dengan penyusunan Rencana Pelaksanaan Pembelajaran Harian (RPPH) oleh bidang kurikulum dimana indikator untuk karakternya disesuaikan dengan kebutuhan yang akan dinilai pada anak dan disetujui oleh kepala sekolah lalu pelaksanaan pembelajaran akan dilakukan oleh guru sentra.

Dalam menentukan kegiatan, guru sentra harus mencari kegiatan yang sesuai dengan Kompetensi Inti dan Kompetensi Dasar (KI-KD) serta Indikator yang telah disusun guru sentra dalam RPP. Guru diwajibkan kreatif agar anak tidak bosan ketika belajar, media pembelajaran setiap minggu harus berganti dan memerlukan kreatifitas yang tinggi untuk membuat media pembelajaran, bisa lihat di internet atau di buku, sebagian ada media yang siap pakai.

Tujuan dari perencanaan ini adalah agar kegiatan pembelajaran dapat berjalan secara sistematis sesuai rencana. Hal ini diungkapkan (Dewayanti, Haenilah, \& Drupadi, 2019, p. 48) Rencana pelaksanaan pembelajaran harian (RPPH) adalah desain kurikulum yang bersifat teknis dan berguna sebagai pedoman pelaksanaan pembelajaran. RPPH mengacu pada program mingguan yang di dalamnya tergambar indikator capaian perkembangan yang menjadi target pembelajaran serta tema yang dijadikan alat untuk merumuskan skenario pembelajaran.

2. Pelaksanaan Internalisasi Nilai-Nilai Karakter Pada Anak Melalui Model Pembelajaran Beyond Centers and Circle Times (BCCT) Di TKIT Luqmanul Hakim

Model pembelajaran BCCT (Beyond Centers and Circle Time) atau yang biasa disebut dengan pembelajaran sentra di TKIT Luqmanul Hakim ini dilaksanakan dalam 7 sentra yakni Sentra Iman dan Taqwa (Imtaq), Sentra Balok, Sentra Persiapan, Sentra Seni dan Kreativitas, Sentra Bermain Peran, Sentra Bahan Alam dan Sentra Musik dan Olah Tubuh. Yang mana anak distimulasi secara aktif dan kreatif melakukan kegiatan bermain dengan berbagai benda dan orang disekitarnya. Sedangkan pendidik lebih berperan sebagai motivator, fasilitator, serta pemberi pijakan.

TKIT Luqmanul Hakim menerapkan model pembelajaran BCCT sudah sesuai dengan prosedur pelaksanaan dan prinsip-prinsip pendekatan BCCT dengan 4 pijakan yaitu pijakan lingkungan bermain, pijakan sebelum bermain, pijakan saat bermain dan pijakan setelah bermain. Pada awal pijakan hingga akhir pijakan terdapat sikap yang ditanamkan dari 18 sikap / karakter pada anak yang dikemukakan oleh Wismiarti (dalam kasali 2019:208) dimana anak akan terbiasa dengan sikap yang mereka lakukan.

Kecerdasan anak sangat di hargai di TKIT Luqmanul Hakim dengan pembelajaran

yang mengembangkan Multiple Intelligence program kegiatan yang sebelumnya ekstrakurikuler dimasukkan ke dalam kegiatan intrakurikuler, yaitu menari, menyanyi, 
futsal, mobis, menggambar, melukis dan angklung. Hal ini didukung oleh Teori kecerdasan jamak (multiple intellegences) dimana Pendekatan model pembelajaran BCCT memandang bahwa setiap anak memiliki kecerdasan yang berbeda-beda sehingga pembelajaran yang dilakukan harus dapat memberikan kebebasan pada anak dalam mengembangkan setiap kecerdasan yang dimilikinya.

Internalisasi nilai-nilai karakter di TKIT Luqmanul Hakim dimana pembinaan nilai karakter di jenjang usia dini adalah pendidikan yang lebih utama dalam hal penanaman karakter karena sebagai dasar utama untuk membentuk karakter mulia. Sebab, untuk mengarungi hidup yang kian menantang ini, pandai saja memang tidak cukup, anak harus dibekali dengan ilmu kehidupan. Dengan sentra, kelas tidak hanya menjadi arena membangun kemampuan akademik anak, tetapi juga membekali anak ilmu kehidupan. Sentra bukan sekedar metode pengajaran agar bisa pandai berprestasi di sekolah. Namun lebih dalam dari itu, metode sentra mengajarkan bagaimana agar seorang anak sukses dalam hidupnya.

Hal ini sejalan dengan Teori konstruktivisme yang dipelopori oleh Jean Piaget dan Lev Vygotsky. Menurut pandangan konstruktivisme, Menurut Budiningsih (2012:58) menjelaskan bahwa Pendekatan konstruktivistik menekankan bahwa peranan utama dalam kegiatan belajar adalah aktivitas siswa dalam mengkonstruksi pengetahuannya sendiri. Segala sesuatu seperti bahan, media, peralatan, lingkungan, dan fasilitas lainnya disediakan untuk membantu pembentukan tersebut. Anak diberi kebebasan untuk mengungkapkan pendapat dan pemikirannya tentang sesuatu yang dihadapinya. Dengan cara demikian, anak akan terbiasa dan terlatih untuk berpikir sendiri, memecahkan masalah yang dihadapinya, mandiri, kritis, kreatif, dan mampu mempertanggung jawabkan pemikirannya secara rasional (Budiningsih, 2005, p. 58)

Tujuan Internalisasi nilai-nilai karakter pada anak melalui BCCT di TKIT Luqmanul Hakim bertujuan untuk menanamkan nilai-nilai mulia pada diri anak, sehingga akan terasa manfaatnya dikemudian hari, manfaat itu akan dirasakan ketika anak menghadapi persoalan dalam hidupnya. Yang paling penting adalah sentra bertujuan untuk membangun 18 nilai karakter anak yang dikembangkan dari nilai-nilai ajaran agama yang didapat dari kitab suci. Basisnya memang agama Islam tetapi berlaku universal dan bersahabat dengan kehidupan.

Nilai-nilai karakter tersebut ada pada Al-Qur'an Surat Luqman ayat 12-19 dimana Nilai-nilai pendidikan karakter yang terkandung dalam Surah Luqman ayat 12-19 tersebut secara garis besar mengandung nilai pendidikan karakter diantaranya: syukur, bijaksana, amal salih, sikap hormat, ramah, sabar, rendah hati, dan pengendalian diri.

Penanaman nilai-nilai karakter anak melalui model pembelajaran BCCT (Beyond Centers and Circle Time) di TKIT Luqmanul Hakim terdapat dalam empat unsur atau konsep dasar dalam menyelenggarakan pembelajaran untuk anak usia dini, yaitu:

a. Teori Pengetahuan (Theory Of Knowledge) dimana Piaget mengatakan bahwa manusia itu mempunyai pengetahuan yang dimiliki oleh setiap individu dalam menjalani hidupnya. TKIT luqmanul Hakim menanamkan 
nilai-nilai karakter anak untuk membentuk karakter mulia sebagai bekal hidup yang kian menantang.

b. Teori perkembangan (theory of development) dimana manusia memiliki pola perkembangan dan karakteristik dari bayi hingga dewasa. Metode sentra mengajarkan bagaimana sikap / karakter agar seorang anak sukses dalam hidupnya.

c. Teori belajar (theory of learning) dimana anak memperoleh pengetahuan yang dapat mengembangkan kemampuan dirinya melalui kegiatan bermain sambil belajar (learning by playing). Dengan sentra, kelas tidak hanya menjadi arena membangun kemampuan akademik anak, tetapi juga membekali anak ilmu kehidupan.

d. Teori Pembelajaran (theory of instruction) dimana Pembelajaran pada anak usia dini selalu mengaplikasikan pendekatan bermain bagi anak. Model pembelajaran BCCT memberikan kesempatan pada anak untuk bermain dan mengeksplorasi permainannya seluas-luasnya sesuai dengan tahapan perkembangannya yang dimiliki oleh individu masing-masing anak.

\section{Evaluasi Internalisasi Nilai-Nilai Karakter Pada Anak Melalui Model Pembelajaran Beyond Centers and Circle Times (BCCT) Di TKIT Luqmanul Hakim}

Evaluasi yang dilaksanaan pada pendidikan karakter TKIT Luqmanul Hakim yaitu menggunakan catatan standar-standar yang harus dicapai anak dan menggunakan catatan anekdot. Evaluasi dari pendidikan karakter juga dapat berupa teguran guru jika ada sifat anak yang kurang baik. Pelaksanaan evaluasi menggunakan catatan anekdot dilakukan untuk melakukan pencatatan mengenai perilaku-perilaku anak, tidak hanya perilaku buruk anak saja yang dicatat namun mencatat juga perilaku baik anak. Penilaian melalui pengamatan dilakukan oleh guru dengan mengamati aktivitas siswa sehari-hari yang berhubungan dengan penanaman nilai karakter.

Penilaian untuk karakter berupa pengamatan dan pencatatan di catatan anekdot dimana ada nilai karakter yang baik dan kurang baik. Jamaris (2006:164) mengatakan bahwa (Jamaris, 2006, p. 164) Evaluasi atau asesmen pada pendidikan anak usia dini merupakan suatu proses kegiatan yang bertujuan untuk mengumpulkan data atau buktibukti tentang perkembangan dan hasil belajar yang berkaitan dengan perkembangan anak usia dini.

\section{Kesimpulan}

Internalisasi Nilai-Nilai Karakter Pada Anak Melalui Model Pembelajaran Beyond Centers and Circle Times (BCCT) Di TKIT Luqmanul Hakim menunjukkan hasil yang memuaskan dan sesuai harapan. Hal ini dapat kita simpulkan dari penelitian diatas bahwa, Perencanaan Internalisasi Nilai-Nilai Karakter Pada Anak Melalui Model Pembelajaran Beyond Centers and Circle Times (BCCT) Di TKIT Luqmanul Hakim diawali dengan 
penyusunan Rencana Pelaksanaan Pembelajaran Harian (RPPH). Perumusan RPP dilakukan seminggu sebelum pembelajaran dimulai. RPP kelas A dan RPP kelas B masing-masing satu minggu. Ada enam kelompok anak yang akan bermain sentra, maka setiap kelompok harus memenuhi kegiatan RPP yang telah disusun perminggunya.

Pelaksanaan Internalisasi Nilai-Nilai Karakter Pada Anak Melalui Model Pembelajaran Beyond Centers and Circle Times (BCCT) Di TKIT Luqmanul Hakim dimana proses pembelajarannya berpusat di sentra main dan saat dalam lingkaran dengan menggunakan 4 jenis pijakan (scaffolding) untuk mendukung perkembangan anak yaitu pijakan lingkungan bermain, pijakan sebelum bermain, pijakan saat bermain dan pijakan setelah bermain. Hal ini sesuai dengan prosedur pelaksanaan dan prinsip-prinsip pendekatan Beyond Centers and Circle Times (BCCT) pembelajaran yang mengembangkan Multiple Intelligence yang sejalan dengan Teori kecerdasan jamak (multiple intellegences). Dengan menginternalisasikan 18 sikap yang diadopsi dari sekolah Al-Falah Ciracas dan Kemendikbud Nomor 137 tahun 2014 yang termasuk dalam aspek perkembangan Nilai Agama dan moral, dan Sosial Emosional diantaranya berperilaku jujur, penolong, sopan, hormat, sportif, dsb, mengenal perasaan sendiri dan mengelolanya secara wajar (mengendalikan diri secara wajar), bertanggung jawab atas perilakunya untuk kebaikan diri sendiri, berbagi dengan orang lain dan menunjukkan sikap toleran.

Evaluasi Internalisasi nilai-nilai karakter pada anak melalui model pembelajaran BCCT (Beyond Centers and Circle Time) di TKIT Luqmanul Hakim menggunakan catatan anekdot dilakukan untuk melakukan pencatatan mengenai perilaku-perilaku anak, tidak hanya perilaku buruk anak saja yang dicatat namun mencatat juga perilaku baik anak. Penilaian untuk karakter berupa pengamatan dan pencatatan di catatan anekdot dimana ada nilai karakter yang baik dan kurang baik. 
Anie Rohanie

\section{BIBLIOGRAFI}

A Doni Koesoema. (2011). Pendidikan Karakter Strategi Mendidik Anak di Zaman Global. Jakarta: PT. Gramedia.

Adisasmita, R. (2006). Pembangunan pedesaan dan perkotaan. Graha Ilmu.

Afifuddin, B. A. S., \& Saebani, B. A. (2012). Metodologi Penelitian Kualitatif, Bandung, Cv. Pustaka Setia.

Budiningsih, A. (2005). Belajar dan pembelajaran. Jakarta: Rineka Cipta.

Dewayanti, L. P., Haenilah, E. Y., \& Drupadi, R. (2019). Pemahaman Pendekatan Saintifik dengan Pengembangan Pembelajaran. Jurnal Pendidikan Anak, 5(2).

Fadlillah, M., \& Khorida, L. M. (2013). Pendidikan karakter anak usia dini. Jogjakarta: Ar-Ruzz Media, 25.

Jamaris, M. (2006). Perkembangan dan pengembangan anak usia taman kanak-kanak. Jakarta: Grasindo.

Muliawan, J. U. (2009). Manajemen Play Group dan Taman Kanak-Kanak. Yogyakarta: Diva Press, Hlm, 254-255.

Rhenald Kasali. (2019). Sentra Inspiring School. Jakarta Selatan: Mizan Media Utama.

Sjarkawi. (2006). Pembentukan Kepribadian Anak. Jakarta: Bumi Aksara.

Sujiono, Y. N., \& Sujiono, B. (2010). Bermain kreatif berbasis kecerdasan jamak. Jakarta: Indeks, 76.

Zubaedi, D. P. K. (2011). Konsepsi dan Aplikasinya dalam Lembaga Pendidikan. Jakarta: Kencana. 